\title{
Reproductive efficiency and survival of Holstein-Friesian cows of divergent Economic Breeding Index, evaluated under seasonal calving pasture-based management
}

\author{
M. O'Sullivan, ${ }^{1,2} \odot$ S. T. Butler, ${ }^{1} \odot$ K. M. Pierce,${ }^{2} \odot$ M. A. Crowe,${ }^{3} \odot$ K. O'Sullivan, ${ }^{4} \oplus$ R. Fitzgerald, ${ }^{1}$ \\ and F. Buckley ${ }^{1,2 *}$ \\ ${ }^{1}$ Animal and Grassland Research and Innovation Centre, Teagasc Moorepark, Fermoy, Co. Cork, P61 C997, Ireland \\ ${ }^{2}$ School of Agriculture and Food Science, University College Dublin, Belfield, Dublin, D04 N2E5, Ireland \\ ${ }^{3}$ School of Veterinary Medicine, University College Dublin, Belfield, Dublin, D04 N2E5, Ireland \\ ${ }^{4}$ School of Mathematical Sciences, University College Cork, Cork, T12 XF62, Ireland
}

\begin{abstract}
The objective of the current study was to examine phenotypic fertility performance and survival, and to gain insight into underlying factors that may contribute to greater fertility performance in 2 divergent genetic groups (GG) of Holstein-Friesian, selected using the Irish Economic Breeding Index (EBI). The GG were evaluated across 3 spring calving pasture-based feeding treatments (FT) over 4 yr. The 2 divergent GG were (1) high EBI; representative of the top 5\% nationally (elite), and (2) EBI representative of the national average (NA). In each year, 90 elite and $45 \mathrm{NA}$ cows were randomly allocated to 1 of $3 \mathrm{FT}$ : control, lower grass allowance, and high concentrate. No interaction between GG and FT was observed for any of the measures of fertility investigated. The elite cows achieved significantly greater pregnancy rate to first service $(+14.9$ percentage points), and significantly greater pregnancy rates after 21,42 , and $84 \mathrm{~d}$ of breeding $(+17.3,+15.2$, and +9.6 percentage points, respectively) compared with NA. The number of services per cow was fewer for elite (1.57) compared with NA (1.80). The interval from mating start date to pregnancy was significantly shorter for elite cows compared with NA. The elite cows maintained greater mean body condition score than NA throughout the study (2.91 vs. 2.72 ), and had greater body condition score at calving, artificial insemination, and drying off compared with NA. The elite cows had greater mean circulating concentrations of insulin-like growth factor-1 compared with NA. No significant effect was observed of GG on commencement of luteal activity, or progesterone profile variables. Greater survival to the start of fifth lactation was observed for elite cows. The elite cows were $43 \%$ less likely to be culled
\end{abstract}

Received July 31, 2019.

Accepted October 13, 2019

*Corresponding author: Frank.Buckley@teagasc.ie than NA by the beginning of the fifth lactation. The results highlight the success of the Economic Breeding Index to deliver reproductive performance and longevity consistent with industry targets across a range of seasonal pasture-based FT. The results also clearly demonstrate the potential of appropriate genetic selection to reverse negative fertility trends incurred during previous decades of selection for milk production alone. Key words: dairy cow, Economic Breeding Index, Holstein-Friesian, reproductive efficiency

\section{INTRODUCTION}

The efficiency of seasonal calving pasture-based milk production systems is dependent on achieving synchrony between feed demand and pasture growth (Shalloo et al., 2007). Maintaining compact calving is a major challenge within pasture-based dairying (Macmillan, 2012), requiring consistent achievement of excellent levels of reproductive performance (O'Farrell, 1994; McDougall, 2006). Failure to maintain compact calving results in financial losses due to reduced pasture utilization, increased costs associated with higher replacement rate (Shalloo et al., 2014), and milk production losses associated with immature herd parity structure (Pritchard et al., 2013).

Declining fertility performance, identified through controlled research (Snijders et al., 2001; Kennedy et al., 2002) and research conducted at the commercial farm level in Ireland (Evans et al., 2006), prompted the development and implementation of a national breeding objective, the Economic Breeding Index (EBI). The EBI incorporates selection for fertility and production, simultaneously reflecting the demands of seasonal calving systems (Veerkamp et al., 2002). Seasonal calving pasture-based systems are relatively unique and account for a small proportion of global milk production ( 10\%; Steinfeld and Mäki-Hokkonen, 1995), and thus, the majority of dairy cattle worldwide have not been 
selected under grazing conditions. Although fertility has recently gained greater emphasis in the selection indices in most countries (Miglior et al., 2005, 2017), the emphasis on fertility and survival varies widely (Miglior et al., 2012; Cole and VanRaden, 2018) and there is no consensus in trait definition or methodology for evaluation (Miglior et al., 2017). Hence, although worldwide genetic trends suggest a reversal in the rate of genetic deterioration of fertility traits, improvement in the phenotypic fertility performance trend is not evident in all countries (Pryce et al., 2014). Strong emphasis is placed on fertility and survival (35\%) within the Irish EBI. Genotypic and phenotypic fertility trends in Irish herds during the past decade indicate improvement (ICBF, 2018), but mean performance at farm level is still behind industry targets (O'Farrell, 1994; McDougall, 2006).

The Next Generation Herd was established at Teagasc, Moorepark, as a sentinel research herd to investigate the anticipated phenotypic performance of futuristic animals selected using EBI. Previous results from the Next Generation Herd study indicate favorable genetic gain for milk solids yield, BCS, and the utilization of ingested energy in cows with high EBI compared with cows with low EBI (O'Sullivan et al., 2019a). The objective of the present study was to examine phenotypic fertility performance and survival, and to gain insight into underlying factors that may contribute to greater fertility performance in cows selected for high EBI. We tested the hypothesis that genetic selection for high EBI results in greater reproductive efficiency and longevity.

\section{MATERIALS AND METHODS}

This study was carried out at the Dairygold Research Farm (Teagasc, Animal and Grassland Research and Innovation Centre, Moorepark, Fermoy, Co. Cork, Ireland; $\left.52^{\circ} 09^{\prime} \mathrm{N} ; 8^{\circ} 16^{\prime} \mathrm{W}\right)$ over a 4 -yr period $(2013-2016)$. Experimental procedures involving animals in the present study were licensed by the Health Products and Regulatory Authority as per the project authorization AE19132/P023, in accordance with the Cruelty to Animals Act (Ireland 1876, as amended by European Communities regulations 2002 and 2005; Department of Health and Children, Ireland, 2005) and the European Community Directive 86/609/EC (Council of the European Union, 1986), and were approved by the Teagasc Animal Ethics Committee.

\section{Animals and Feeding Treatments}

Two genetic groups (GG) of Holstein-Friesian (HF) cows were compared. The GG within the Next Genera- tion Herd were described in detail by O'Sullivan et al. (2019b). Briefly, the 2 GG compared were high EBI, within the top 5 percentile of cows nationally, ranked on EBI (elite), and cows representative of the national average genetic merit (NA). The mean EBI and EBI sub-index values for milk, fertility, calving, beef, maintenance, health, and PTA for calving interval and survival, for the elite and NA cows, excluding the influence of both own and progeny performance, are summarized in Table 1 (ICBF, 2018). Each year, 90 elite and 45 NA cows were randomly assigned in mid-March and midApril, for the early and late calving cows, respectively, to 1 of 3 experimental feeding treatments (FT). Both GG were balanced for parity and calving date each year. The 3 experimental FT were control (CTL), high concentrate (HC), and lower grass allowance (LGA), characterized by target postgrazing compressed sward heights of 4.5 to $5 \mathrm{~cm}, 4.5$ to $5 \mathrm{~cm}$, and 3.5 to $4 \mathrm{~cm}$, and planned concentrate allowances of $300,1,100$, and $300 \mathrm{~kg}$ per cow per year, respectively. The $3 \mathrm{FT}$ were designed to represent management scenarios reflective of the upper and lower limits of recommended best practice to maximize productivity in Irish milk production systems (O'Donovan et al., 2011). Details of the pasture management and grass quality were reported by O'Sullivan et al. (2019a,b).

\section{Reproductive Management}

Before the mating start date (MSD) each year, all cows greater than 30 DIM were examined using transrectal ultrasonography (Ibex Pro scanner with an 8.5 $\mathrm{MHz}$ transducer, E.I. Medical Imaging, Loveland, CO) to assess uterine and ovarian status. The incidence of reproductive disorders (endometritis, pyometra, ovarian cysts, anovulatory anestrus) was recorded. Intervention to treat anovulatory anestrous cows was not under-

Table 1. The mean and SD of Economic Breeding Index (EBI), EBI sub-indexes, and PTA for fertility traits of the 2 genetic groups of Holstein-Friesian studied ${ }^{1}$

\begin{tabular}{lcc}
\hline Item & Elite $(\mathrm{SD})$ & NA $(\mathrm{SD})$ \\
\hline EBI & $154 \pm 34.2$ & $47 \pm 30.9$ \\
Sub-index & $28 \pm 20.0$ & $7 \pm 17.5$ \\
Milk $(€)$ & $103 \pm 28.9$ & $28 \pm 22.7$ \\
Fertility $(€)$ & $31 \pm 8.0$ & $24 \pm 8.6$ \\
Calving (€) & $-21 \pm 7.6$ & $-13 \pm 8.0$ \\
Beef $(€)$ & $12 \pm 8.5$ & $2 \pm 8.9$ \\
Maintenance $(€)$ & $0 \pm 4.6$ & $-1 \pm 4.6$ \\
Health $(€)$ & & \\
PTA & $-5.2 \pm 1.74$ & $-1.21 \pm 4.6$ \\
Calving interval $(d)$ & $3.13 \pm 1.01$ & $1.14 \pm 0.91$ \\
Survival $(\%)$ &
\end{tabular}

${ }^{1}$ Genetic group of Holstein-Friesian: Elite = high EBI; NA = national average EBI. 
taken before wk 7 of the breeding season to allow cows express their inherent reproductive potential. A total of 9 anovulatory anestrous cows received a progesteroneovsynch protocol, previously described by (Cummins et al., 2012a), after wk 7 of the breeding season over the 4 yr (6 elite, 3 NA; 0.03 of each GG). All experimental animals were tail-painted twice weekly as part of the normal management practice to aid identification of estrous events, commencing 3 wk before MSD. During the breeding season, heat detection was carried out a minimum of 3 times daily with the aid of tail paint, and activity monitoring collars (MooMonitor, Dairymaster, Causeway, Co. Kerry, Ireland) were fitted to each animal before parturition. The breeding season commenced on April 25 of each year, and lasted for 12 wk. Cows that were observed standing to be mounted, or that had tail paint removed and showed physical signs of estrus, were drafted for AI. During wk 1 to 6 of the breeding season, cows detected in heat were inseminated with frozen-thawed semen from a bull, chosen from a team of genomically selected young sires of the highest EBI. The same team of bulls was used across both GG. Cows displaying estrus during the breeding season were inseminated regardless of calving date and the same inseminator performed all AI events for each year of the study. Cows detected in estrus were inseminated once daily, after morning milking. For each sire used, semen was from a single ejaculate, and sperm viability and quality were verified before use in the experiment. During wk 7 to 12 of the breeding season, natural service was carried out by easy-calving Aberdeen Angus bulls. Bulls underwent a breeding soundness evaluation before joining the experimental herds. Pregnancy diagnosis was carried out by transrectal ultrasound at 30 to $36 \mathrm{~d}$ and again at 60 to 66 d postinsemination to determine pregnancy status and embryo loss. Final pregnancy status was determined by transrectal ultrasound $80 \mathrm{~d}$ after the completion of the breeding season. These ultrasound examination records were used to assign a pregnancy date for every cow.

\section{Reproductive Measurements}

The reproductive measurements that were calculated were as follows: 21-d submission rate; proportion of all cows inseminated within the first $21 \mathrm{~d}$ of the breeding season; pregnancy rate to first service (proportion of cows pregnant to first service confirmed by ultrasound scan during and after the end of the breeding season); 21-d pregnancy rate (Preg21; proportion of cows that became pregnant during the first $21 \mathrm{~d}$ of the breeding season confirmed by ultrasound scans during and after the end of the breeding season); 42-d pregnancy rate
(Preg42; proportion of cows that became pregnant during the first $42 \mathrm{~d}$ of the breeding season confirmed by ultrasound scans during and after the end of the breeding season); 84-d pregnancy rate (Preg84; proportion of cows pregnant by d 84 of the breeding season, confirmed by ultrasound scan $80 \mathrm{~d}$ after the end of the breeding season); MSD to first-service interval; MSD to pregnancy interval; services per cow (number of times each cow was served during the breeding season); embryonic loss (proportion of cows that did conceive (pregnant at 30 to $36 \mathrm{~d}$ postservice) but did not remain pregnant (nonpregnant at 60 to $66 \mathrm{~d}$ postservice, or after the end of the breeding season).

\section{$B W$ and BCS}

Body weight was recorded weekly using calibrated electronic scales (Dairymaster, Causeway, Co. Kerry, Ireland). Body condition score was recorded every 2 wk in early lactation (up to wk 10 of lactation), and approximately every 3 to 4 wk thereafter by a single evaluator. The scale used was 1 to 5 (with 1 being extremely thin and 5 being extremely fat), with increments of 0.25 (Edmonson et al., 1989). Variables calculated included BW and BCS at calving (measured on the week of calving or less than 2 wk before calving), $\mathrm{BW}$ and BCS nearest $\mathrm{AI}$, and $\mathrm{BW}$ and BCS at the end of lactation. The week of BCS nadir was determined by identifying the earliest postpartum occurrence of the lowest BCS value recorded during the first 15 wk of lactation. Changes in BCS from calving to BCS nearest $\mathrm{AI}$, and from the BCS nearest AI to end of lactation, were calculated.

\section{Blood Metabolite and Hormone Analysis}

Blood samples were collected via coccygeal venipuncture using 21-gauge vacutainer needles into $10-\mathrm{mL}$ lithium heparin vacutainer tubes (Becton Dickinson, Plymouth, UK). All blood samples were centrifuged at $1,500 \times g$ for $15 \mathrm{~min}$ at $4^{\circ} \mathrm{C}$; the plasma was harvested and aliquoted into two 3.5-mL plasma tubes (Sarstedt, Nümbrecht, Germany) and stored at $-20^{\circ} \mathrm{C}$ until later analysis. Plasma samples collected at wk $-2,1,2,34$, 6,8 , and 10 relative to parturition were analyzed for concentrations of plasma fatty acids, BHB, and glucose by enzymatic colorimetry using an ABX Pentra 400 autoanalyzer (ABX Mira, Montpellier, France; fatty acids kit supplied by Wako Chemicals GmBH, Neuss, Germany; BHB kit supplied by Randox Laboratories Limited, Crumlin, Co. Antrim, United Kingdom; Glucose kit supplied by Horiba ABX, Montpellier, France). Plasma samples collected at wk $-2,1,2,4,6,8$, and 10 
relative to parturition were analyzed for concentrations of insulin and IGF-1. Concentrations of insulin were determined using an immunoradiometric assay (DIAsource ImmunoAssays, Louvain-la-Neuve, Belgium). Concentrations of IGF-1 were determined using a validated double antibody RIA following ethanol: acetone: acetic acid extraction (Beltman et al., 2010). Inter- and intraassay coefficients of variation were 3.6 and $7.5 \%$ for insulin and 4.4 and $10.8 \%$ for IGF-1, respectively.

\section{Milk Progesterone}

Milk samples were collected using electronic milk meters (Dairymaster, Causeway, Co. Kerry, Ireland), during the p.m. milking 3 times/wk (Monday, Wednesday, Friday) from parturition until wk 5 after MSD for progesterone (P4) analysis to determine interval from calving to resumption of cyclicity and estrous cycle characteristics. After milking, samples were aliquoted into 96-well MegaBlocks (Sarstedt, Nümbrecht, Germany) and stored at $-20^{\circ} \mathrm{C}$ until $\mathrm{P} 4$ analysis. Milk P4 concentrations were measured using an ELISA (Ridgeway Science, Gloucestershire, UK). Cows were considered to have an active corpus luteum when milk $\mathrm{P} 4$ concentrations exceeded $3 \mathrm{ng} / \mathrm{mL}$. Using the milk P4 profile, estrous cycle characteristics including the commencement of luteal activity (C-LA), luteal phase (LP) duration, inter-ovulatory interval (IOI), interluteal interval (ILI), delayed ovulation type I (DOVI), delayed ovulation type II (DOVII), persistent corpus luteum type I (PCLI), and persistent corpus luteum type II (PCLII) were calculated for each individual cow as previously described (Horan et al., 2005).

\section{Survival Analysis}

Data from cows that participated in the study between 2013 and 2016 were included in the survival analysis, including cows that had left the experimental herd (i.e., surplus cows and those sold to commercial herd-owners). Date and reason for culling were recorded for all animals. Re-calving and survival data for all cows that participated in the study between 2013 and 2016 were extracted from the Computerised Cattle Movement Monitoring System database operated by the Department of Agriculture, Food and the Marine. A total of 122 elite and $55 \mathrm{NA}$ animals were pregnant at the end of the study; these animals were assumed censored on the last day of 2016, as their ultimate survival time was unknown. All animals culled due to infertility were assigned the status of culled on the date of drying off at the end of lactation. Survival was defined as the numbers of days from first calving to the date of culling.

\section{Statistical Analysis}

All statistical analyses were carried out using SAS (version 9.4, SAS Institute Inc., Cary, NC). The effect of GG was of primary interest in the current study. The timing of FT implementation meant the effect of FT on blood metabolites and hormonal status, particularly in the early lactation period, was not captured. However, the effect of FT was included in all statistical models for completeness and its interaction with GG was considered. The effect of GG on variables with repeated measures, such as BCS, BW, and blood metabolite and hormone concentrations, was determined using mixed models. The effects of GG, FT, parity, calving date, year, lactation, week, and their interactions were included in the final model where significant $(P<0.05)$, with cow nested within GG included as a random effect. Each model was tested using 4 different covariance structures (autoregressive order one, autoregressive order one with heterogeneous variance, compound symmetry, and unstructured). The model and covariance structure with the lowest Akaike's information criterion was used to identify the most appropriate residual covariance structure for repeated measures. A compound symmetry error structure was determined as the most appropriate residual covariance structure for repeated measures. Plasma IGF-1, fatty acids, and BHB concentrations were transformed to generate a normal distribution and the estimated group means and 95\% confidence intervals were derived from back-transformed values. The final model used was

$$
\begin{aligned}
\mathrm{R}_{i j k l m}=\mu & +\mathrm{Y}_{i}+\mathrm{G}_{j}+\mathrm{F}_{k}+\mathrm{L}_{l}+\mathrm{W}_{m} \\
& +\mathrm{G}_{j} \times \mathrm{W}_{m}+\mathrm{e}_{i j k l m},
\end{aligned}
$$

where $\mathrm{R}_{i j k l m}=$ the observation for the dependent variable (BW, BCS, insulin, IGF-1, glucose, fatty acids, and BHB concentrations); $\mathrm{Y}_{i}=$ the effect of $i$ th year $(i$ $=1,2,3,4) ; \mathrm{G}_{j}=$ the effect of the $j$ th genetic group $(j$ $=$ elite, NA); $\mathrm{F}_{k}=$ the effect of the $k$ th feeding treatment $\left(k=\right.$ CTL, HC, LGA); $\mathrm{L}_{l}=$ the effect of the $l$ th parity, $\mathrm{W}_{m}=$ the effect of the $m$ th week of lactation; $\mathrm{G}_{j}$ $\times \mathrm{W}_{m}=$ the interaction between genetic group $j$ and lactation week $m$, and $\mathrm{e}_{i j k l m}=$ the residual error term.

The effect of GG on continuous variables without repeated measures such as MSD to first-service interval, MSD to pregnancy interval, number of services per cow, and selected BW and BCS variables (i.e., BW and BCS at calving, postpartum BW and BCS nadir, week of BCS nadir, BW and BCS nearest AI, BW and BCS at the end of lactation, and changes in BW and BCS from calving to AI, calving to nadir, and from nadir to end of lactation) were determined using a mixed 
model (PROC MIXED; SAS Institute Inc.) with cow nested within GG as a random effect. The effect of GG, FT, parity, and their interactions were tested, calving date and year were included as adjustment variables. Interactions that were nonsignificant $(P>0.05)$ were eliminated from the final model:

$$
\mathrm{R}_{i j k l}=\mu+\mathrm{Y}_{i}+\mathrm{G}_{j}+\mathrm{F}_{k}+\mathrm{L}_{l}+\mathrm{e}_{i j k l}
$$

where $\mathrm{R}_{i j k l}=$ the observation on the animal for the dependent variable (BW and BCS at calving, postpartum BW and BCS nadir, week of BCS nadir, BW and BCS nearest $\mathrm{AI}, \mathrm{BW}$ and $\mathrm{BCS}$ at the end of lactation, and changes in BW and BCS from calving to AI, calving to nadir, and from nadir to the end of lactation) in year $i$, of parity $j$, and genetic group $k$, on feeding treatment $l ; \mathrm{Y}_{i}=$ the effect of $i$ th year $(i=1,2,3,4) ; \mathrm{G}_{j}=$ the effect of the $j$ th genetic group $\left(j=\right.$ elite, NA); $\mathrm{F}_{k}=$ the effect of the $k$ th feeding treatment $(k=\mathrm{CTL}, \mathrm{HC}$, LGA); $\mathrm{L}_{l}=$ the effect of the lth parity, and $\mathrm{e}_{i j k l}=$ the residual error term.

Differences between GG for variables with a binomial distribution (21-d submission rate, pregnancy rate to first service, Preg21, Preg42, and Preg84) were tested using generalized linear mixed models (PROC GLIMMIX), with a binary distribution specified in the model statement. The final model was

$$
\mathrm{R}_{i j k l}=\mu+\mathrm{Y}_{i}+\mathrm{G}_{j}+\mathrm{F}_{k}+\mathrm{L}_{l}+\mathrm{e}_{i j k l}
$$

where $\mathrm{R}_{i j k l}=$ the observation on the animal for the dependent variable (21-d submission rate, pregnancy rate to first service, Preg21, Preg42, and Preg84) in year $i$, and genetic group $j$, on feeding treatment $k$, of parity $l ; \mathrm{Y}_{i}=$ the effect of $i$ th year $(i=1,2,3,4) ; \mathrm{G}_{j}=$ the effect of the $j$ th genetic group $(j=$ elite, $\mathrm{NA}) ; \mathrm{F}_{k}=$ the effect of the $k$ th feeding treatment $(k=$ CTL, HC, LGA); $\mathrm{L}_{l}=$ the effect of the lth parity, and $\mathrm{e}_{i j k l}=$ the residual error term.

Data from 272 cows (177 elite, 95 NA) that entered the study were included in the survival analysis. KaplanMeier survival probabilities were derived by defining GG as strata in PROC LIFETEST. Differences in the survival experience of both GG were estimated using the log-rank test. The effect of GG on cow survival was analyzed by the Cox proportional hazards model using PROC PHREG of SAS. Effects were expressed as relative hazard ratios. The elite were the reference class (i.e., their hazard ratio was set to 1). Therefore, a relative hazard ratio greater than 1 indicates a higher risk of culling (i.e., lower survivability).

\section{RESULTS}

\section{Reproduction and Fertility}

Mean calving date over the 4-yr study period was February $15( \pm 16 \mathrm{~d})$ and $18( \pm 18 \mathrm{~d})$ for elite and NA cows, respectively, and the calving period ranged from January 6 to April 12. The interaction between GG and FT was not significant for any of the fertility variables investigated, and was therefore omitted from final statistical models. The effect of GG on reproductive performance is summarized in Table 2. Pregnancy rate to first service, Preg21, Preg42, and Preg84 was greater $(+14.9,+17.3,+15.2$, and +9.6 percentage points, respectively; $P<0.001)$ for elite compared with NA. The number of services per cow was fewer $(P<0.01)$ for elite compared with NA. While numerically lower for elite, the proportion of embryo mortality did not differ significantly between elite and NA. The interval from MSD to first service tended to be shorter for elite cows

Table 2. The effect of genetic group (GG) of Holstein-Friesian dairy cow on reproductive performance during

\begin{tabular}{|c|c|c|c|c|}
\hline \multirow[b]{2}{*}{ Item } & \multicolumn{2}{|c|}{ GG } & \multirow[b]{2}{*}{ SEM } & \multirow[b]{2}{*}{$P$-value } \\
\hline & Elite & NA & & \\
\hline 21-d submission rate $(\%)$ & 93.2 & 88.1 & - & 0.07 \\
\hline Pregnancy rate to first service (\%) & 60.4 & 45.5 & - & 0.001 \\
\hline Preg21 (\%) & 53.1 & 35.7 & - & 0.001 \\
\hline Preg42 (\%) & 72.7 & 57.5 & - & 0.001 \\
\hline Preg84 (\%) & 92.7 & 83.1 & 0.02 & 0.01 \\
\hline MSD to first service interval (d) & 13.8 & 16.0 & 0.85 & 0.07 \\
\hline MSD to pregnancy interval (d) & 25.3 & 31.1 & 1.55 & 0.01 \\
\hline No. of services per cow & 1.57 & 1.80 & 0.06 & 0.01 \\
\hline Embryo mortality (\%) & 3.8 & 6.4 & - & 0.27 \\
\hline
\end{tabular}
a 12 -wk breeding season ${ }^{1}$

${ }^{1}$ Elite = high Economic Breeding Index; NA = national average Economic Breeding Index; Preg21 = 21-d pregnancy rate; Preg $42=42$-d pregnancy rate; Preg $84=84$-d pregnancy rate; MSD = mating start date. 
$(P=0.07)$, and the interval from MSD to pregnancy was significantly shorter $(-5.8 \mathrm{~d} ; P<0.01)$ for elite cows compared with NA.

\section{$B W$ and BCS}

The BW profile of both GG from wk -2 to 42 of lactation is illustrated in Figure 1. Mean BW (Table 3) was greater for NA cows compared with elite $(+12$ $\mathrm{kg}, P<0.01)$. A significant GG by week interaction for BW $(P<0.05)$ was observed. A tendency was observed for greater $\mathrm{BW}$ at calving for NA cows compared with elite $(P=0.08)$. Body weight at AI $(P<0.05)$ and BW at drying off $(P<0.05)$ were greater for NA cows compared with elite. Body weight changes from calving to AI, calving to nadir, and nadir to drying off did not differ significantly between elite and NA. Elite cows maintained greater mean BCS $(+0.19$ units, $P<0.001)$ throughout the study compared with NA (Table 3). No interaction was observed between GG and FT detected for BCS $(P=0.33)$. The elite cows had greater BCS at calving, nearest AI, and drying off compared with NA. The elite cows had greater BCS at nadir $(P<$ 0.001). No significant differences were observed for the week of lactation when nadir BCS occurred. Changes in BCS from parturition to nadir, and from nadir to drying off did not differ significantly between GG. The BCS profile of both GG from wk -2 to 42 of lactation is illustrated in Figure 2. No significant interaction between GG and week of lactation was observed $(P=$ $0.11)$.

\section{Circulating Concentrations of Blood Metabolites and Metabolic Hormones}

The temporal profiles of circulating blood metabolites and hormones during the prepartum and early lactation period (wk -2 to 10) are illustrated in Figures 3 and 4 , respectively. Interactions between GG and week were not significant for glucose, BHB, or fatty acids. A tendency for greater plasma glucose concentrations was observed for elite animals compared with NA (70.3 \pm 0.8 vs. $68.2 \pm 1.01 \mathrm{mg} / \mathrm{dL} ; P=0.07)$. The elite cows had lower circulating BHB concentrations compared with NA $(0.91 \pm 0.004$ vs. $0.93 \pm 0.006 \mathrm{mmol} / \mathrm{L} ; P$ $=0.04)$. The NA cows had lower circulating fatty acid concentrations compared with elite $(0.86 \pm 0.003$ vs. $0.87 \pm 0.005 \mathrm{mmol} / \mathrm{L} ; P=0.04)$. The elite cows had greater mean circulating concentrations of IGF-1 compared with NA $(109.87 \pm 34.92$ vs. $99.96 \pm 38.07 \mathrm{ng} /$ $\mathrm{mL} ; P=0.002)$. A tendency for higher mean circulating concentrations of plasma insulin was observed for elite cows during the sampling period $(P>0.06)$. A GG by time interaction was observed for insulin. The elite cows had greater circulating concentrations of insulin $(P<0.01)$ at 2 wk before parturition, but postpartum insulin concentrations did not differ.

\section{P4 Profiles}

No significant effect was observed of GG on C-LA, first and second LP length, first and second ILI, and first and second IOI (Table 4). The number of luteal

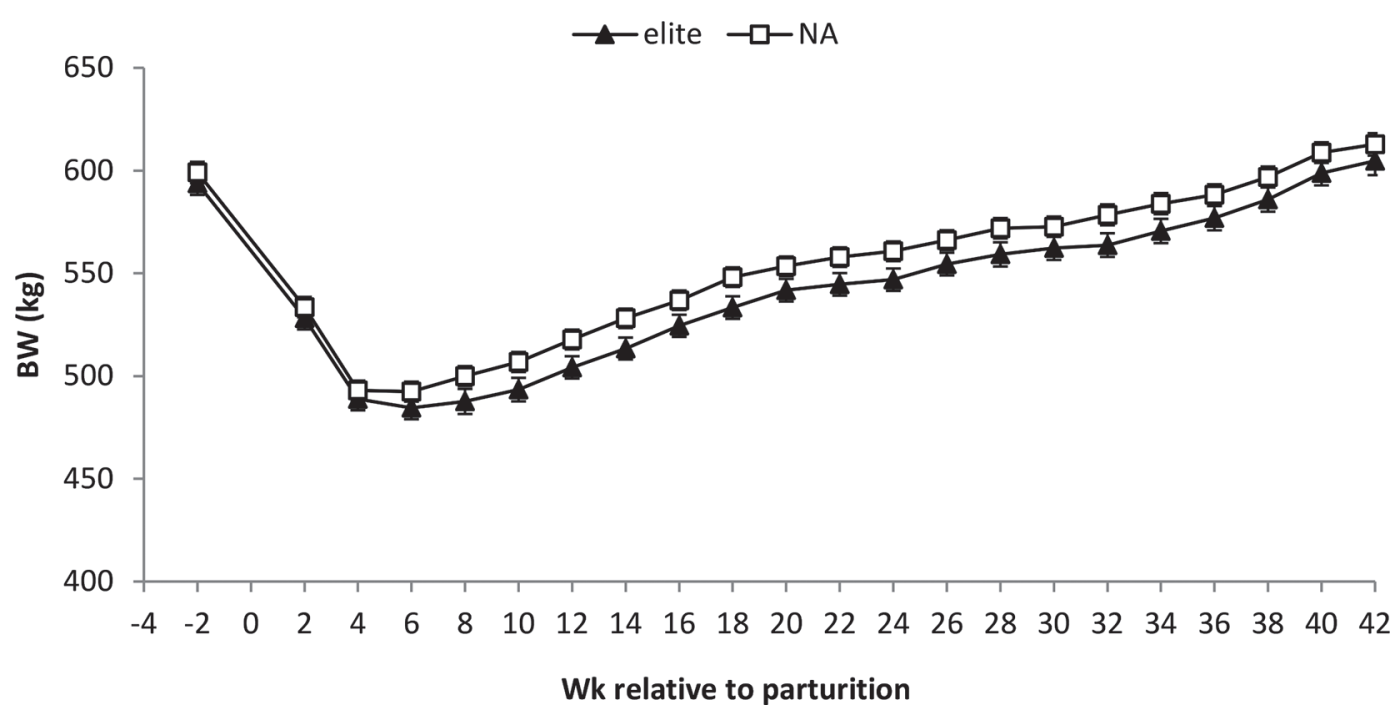

Figure 1. The mean BW profile of high Economic Breeding Index (elite) and national average Economic Breeding Index (NA) cows during the gestation-lactation cycle. Data are presented as LSM, and error bars represent the SEM. The NA cows maintained greater mean BW $(P<$ $0.01 ; \mathrm{SEM}=3.70$ ) than elite cows from prepartum to the end of the lactation. 
phases in the first $60 \mathrm{~d}$ postpartum did not differ significantly between GG. Peak P4 concentration during the first and second luteal phases did not differ significantly between GG. The incidence of DOVI, DOVII, PCLI, and PCLII was 7.3, 1.6, 2.8, and $1.0 \%$ for elite cows and 7.8, 0.4, 3.1, and 1.5\% for NA cows. Genetic group had no significant effect $(P<0.05)$ on any of the ovarian disorders investigated.

\section{Survival}

Age at first calving for the elite and NA was $667 \mathrm{~d}$ (SD 35.3), and $651 \mathrm{~d}$ (SD 57.8), respectively. Figure 5 illustrates the survival curves to the beginning of the 5th lactation over the study period for each GG. A total of $59.3 \%$ of the elite, and $38.7 \%$ of the NA were treated as right censored in the data set due to unknown final survival time after completion of the current study. The elite were $43 \%$ less likely to be culled than NA $(P<$ 0.01) by the beginning of the fifth lactation.

\section{DISCUSSION}

Dairy cow selection indices have changed markedly during the last 25 yr (Lucy, 2019). Selection objectives have evolved from single trait selection for milk production to multi-trait selection incorporating many nonyield traits such as fertility, health, and fitness traits (Miglior et al., 2017; Cole and VanRaden, 2018). Genomic selection has accelerated the rate of genetic progress in dairy cows (Bouquet and Juga, 2013), but rapid progress can lead to unexpected outcomes (Lucy, 2019). Historical selection for high milk production has been associated with deterioration in fertility (Pryce et al., 2004), and has been reported in several studies (Snijders et al., 2001; Washburn et al., 2002; Veerkamp et al., 2003; Evans et al., 2006). Controlled experiments on animals divergent for the breeding goal can be efficiently used to elucidate the expected responses to selection for difficult or expensive-to-measure traits (Berry, 2015). For example, greater fertility performance has been observed in strains of HF selected under grazing conditions compared with strains sourced from largely confinement systems (Horan et al., 2004; McCarthy et al., 2007a). Furthermore, Cummins et al. (2012a,b) and Moore et al. (2014) validated a novel lactating Holstein-Friesian cow model of fertility, identifying a range of physiological factors that differ between cows with good or poor genetic merit for fertility traits. These included BCS, hormones and energy metabolites, and ovarian function.

\section{Reproductive Efficiency}

The superior reproductive performance observed in elite cows in the present study is consistent with greater

Table 3. The effect of genetic group (GG) of Holstein-Friesian on mean BW and BCS variables ${ }^{1}$

\begin{tabular}{|c|c|c|c|c|c|}
\hline \multirow[b]{2}{*}{ Variable } & \multicolumn{2}{|c|}{ GG } & \multirow[b]{2}{*}{ SEM } & \multicolumn{2}{|c|}{$P$-value } \\
\hline & Elite & NA & & GG & $\mathrm{GG} \times$ week \\
\hline \multicolumn{6}{|l|}{$\mathrm{BW}$} \\
\hline Mean BW (kg) & 534.6 & 546.6 & 3.70 & $<0.01$ & $<0.05$ \\
\hline BW at calving ${ }^{2}(\mathrm{~kg})$ & 595.1 & 607.3 & 5.13 & 0.08 & - \\
\hline BW nearest AI (kg) & 514.3 & 524.5 & 3.86 & $<0.05$ & - \\
\hline BW at the end of lactation (kg) & 575.4 & 589.5 & 4.37 & $<0.05$ & - \\
\hline BW change & & & & & - \\
\hline Calving to $\mathrm{AI}(\mathrm{kg})$ & 81.4 & 84.2 & 4.23 & 0.63 & - \\
\hline Calving to nadir (kg) & 43.1 & 38.2 & 2.18 & 0.10 & - \\
\hline Nadir to end of lactation (kg) & 106.0 & 110.8 & 2.93 & 0.19 & - \\
\hline \multicolumn{6}{|l|}{ BCS } \\
\hline Mean BCS & 2.91 & 2.72 & 0.16 & $<0.001$ & 0.11 \\
\hline BCS at calving $^{3}$ & 3.25 & 3.03 & 0.03 & $<0.001$ & - \\
\hline BCS nearest AI & 2.92 & 2.75 & 0.02 & $<0.001$ & - \\
\hline BCS at the end of lactation & 2.96 & 2.70 & 0.02 & $<0.001$ & - \\
\hline BCS at nadir & 2.85 & 2.63 & 0.03 & $<0.001$ & - \\
\hline Week of nadir (wk) & 9.8 & 10.2 & 1.35 & 0.77 & - \\
\hline BCS change & & & & & - \\
\hline Calving to AI & 0.33 & 0.28 & 0.03 & 0.52 & - \\
\hline Calving to nadir & 0.40 & 0.41 & 0.03 & 0.97 & - \\
\hline Nadir to end of lactation & 0.11 & 0.7 & 0.03 & 0.26 & - \\
\hline
\end{tabular}


genetic merit for fertility traits in the elite GG. The reproductive performance achieved by the elite cows in the present study was consistent with recommended industry targets (O'Farrell, 1994; McDougall, 2006), whereas the NA cows did not achieve the industry targets. The reproductive performance achieved by the elite cows indicates substantial genetic progress in genetic and phenotypic fertility has been achieved, reversing the trends previously reported at the same research institute (Buckley et al., 2000; Snijders et al., 2001; Horan et al., 2004) and at the commercial farm level (Evans et al., 2006). The findings support the hypotheses of Pryce and Veerkamp (2001) and Veerkamp et al. (2002) that incorporation of fertility traits into genetic selection indexes can lead to improved fertility performance.

Despite the recent inclusion of reproduction traits and various fertility indicator traits in selection indices internationally (Miglior et al., 2017; Cole and VanRaden, 2018), modest improvements have been achieved (Fleming et al., 2019). Worldwide genetic and phenotypic fertility trends vary significantly across countries (Pryce et al., 2014). While none of the modern selection indices used globally are based solely on milk fat and protein production (Lucy, 2019), milk production traits still typically comprise approximately $50 \%$ of the total index in many countries, with fertility and survival traits typically comprising less than $30 \%$ of the total index (Cole and VanRaden, 2018). The findings from the current study indicate that high weighting on direct fertility traits within selection objectives is required if improvements in phenotypic fertility performance are required in the short to medium term.

\section{$B W$ and $B C S$}

The lower mean BW of elite cows compared with NA cows in the present study is consistent with their greater maintenance sub-index and lower beef merit. The lower BW of the elite cows reflects the overall selection objective of breeding moderate-sized dairy cows requiring less energy for maintenance, whereby a negative economic weighting ( $-€ 1.65$ per $\mathrm{kg}$ cull cow weight) is placed on cow size in the EBI (ICBF, 2017). Selection for smaller cows should result in a smaller maintenance energy requirement, and thus, any extra feed above that needed for maintenance can be converted to milk or body tissues (VandeHaar et al., 2016). It is well established that BCS is a key driver of cow fertility (Berry et al., 2003; Buckley et al., 2003; Weigel, 2006; Cummins et al., 2012b). Heritability estimates for BCS range from 0.07 to 0.60 (Berry et al., 2008), indicating that BCS is under considerable genetic control. Body condition score can be considered a predictor of fertility in dairy cattle populations where direct assessment of reproductive fitness is not included in the total merit index (Tiezzi et al., 2013). It is likely that the greater BCS observed in elite cows in the present study is an indirect outcome of the high weighting on fertility within the EBI. Conversely, low emphasis on direct fer-

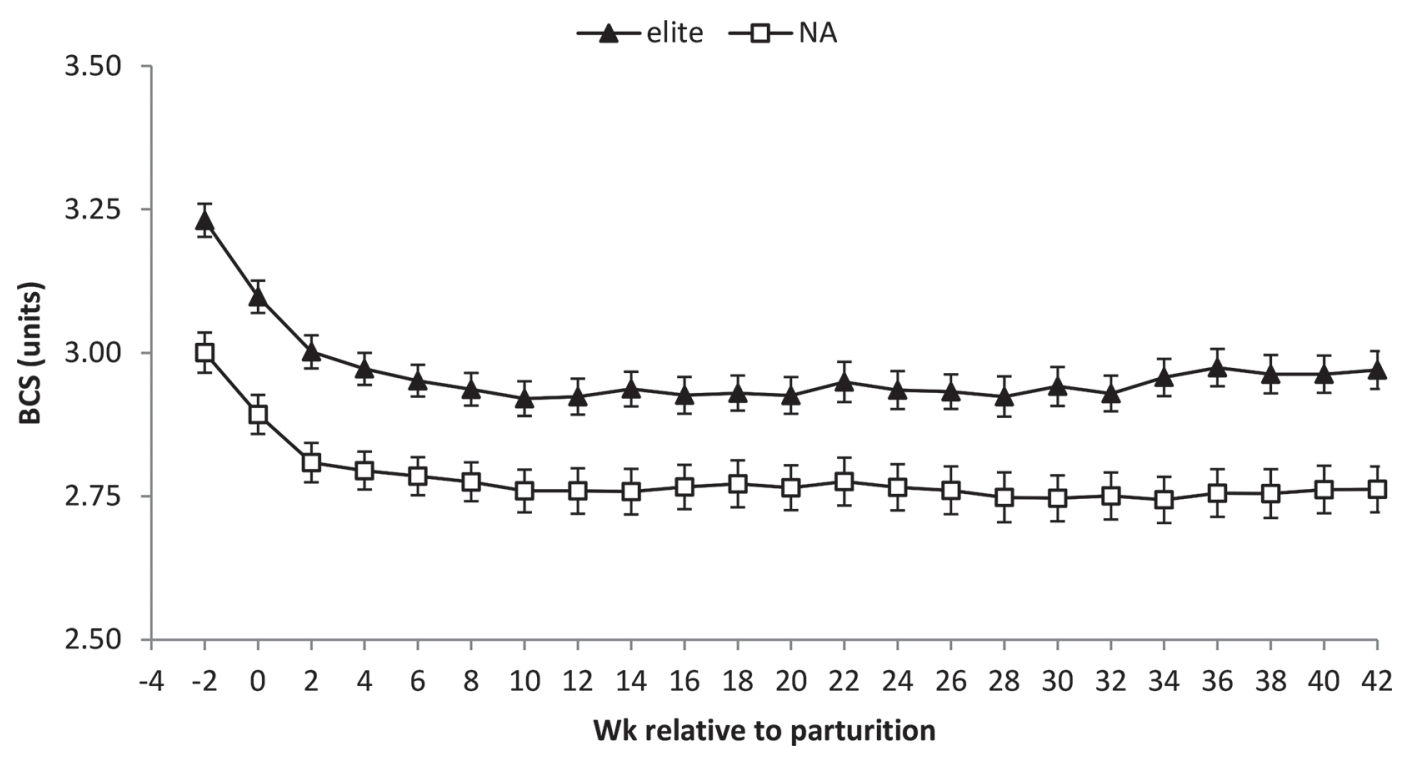

Figure 2. The mean BCS profile of high Economic Breeding Index (elite) and national average Economic Breeding Index (NA) cows during the gestation-lactation cycle. Data are presented as LSM, and error bars represent the SEM. Elite cows maintained greater mean BCS $(P<$ 0.001 ; SEM $=0.16$ ) than NA cows from prepartum to the end of the lactation. 
tility traits within selection indices in many countries (Miglior et al., 2012) perhaps limits the opportunity for indirect increases in BCS in these countries. Strong positive correlations between both genetic (Pryce et al., 2001; Veerkamp et al., 2001; Berry et al., 2003) and phenotypic (Domecq et al., 1997; Buckley et al., 2003; Zink et al., 2011) BCS and reproductive performance have been reported, and BCS has recently been incorporated as a selection trait in New Zealand representing 7\% of the Breeding Worth index (DairyNZ, 2019).

In the present study, greater EBI resulted in greater BCS in elite cows at calving and during the breeding season, and suggests a genetic disposition to maintain minimum threshold BCS levels for optimum reproduc-
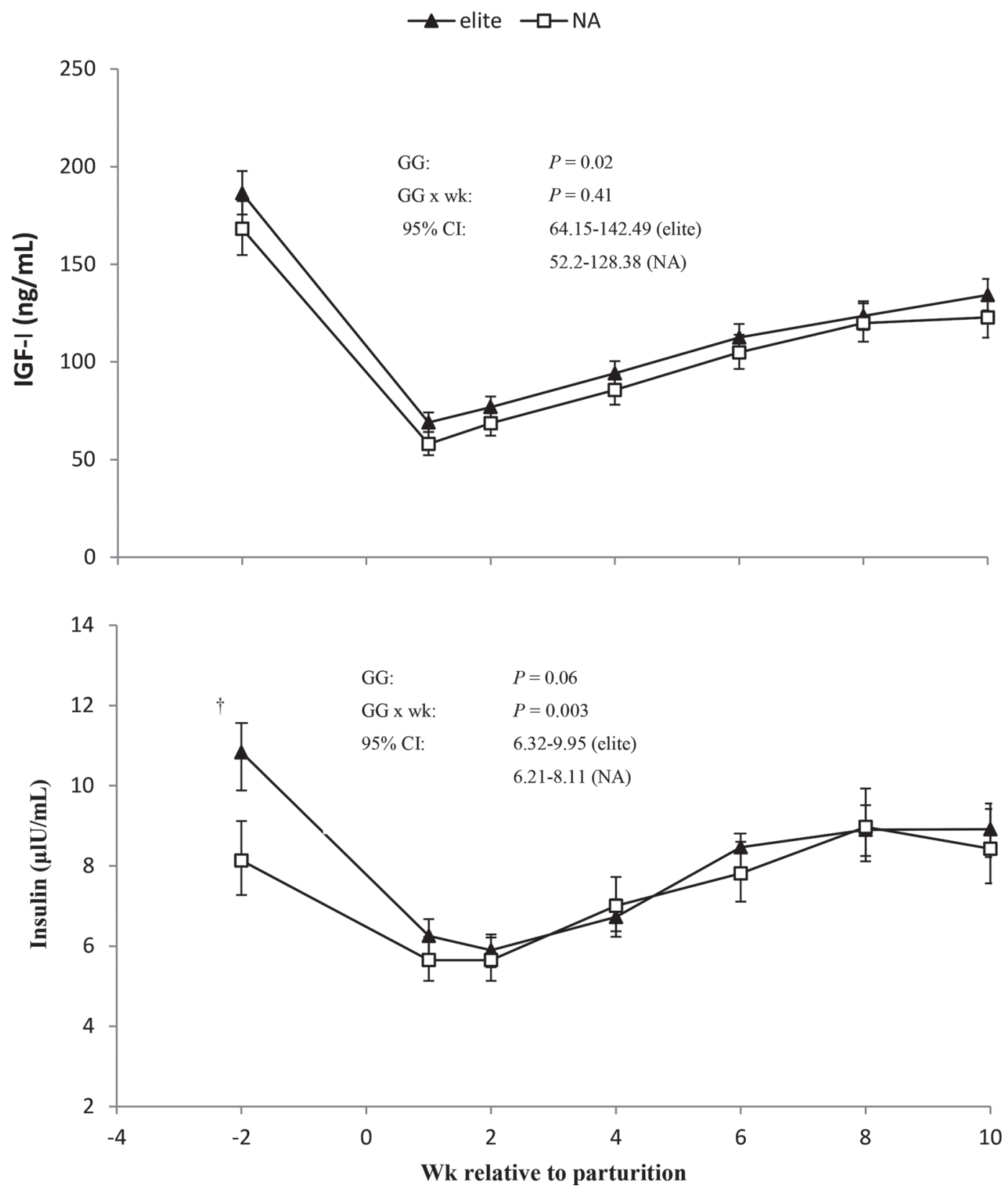

Figure 3. Mean circulating IGF-I and insulin concentrations in high Economic Breeding Index (elite) and national average Economic Breeding Index (NA) cows from wk -2 to 10 relative to parturition. Plasma IGF-I was greater in elite cows than in NA cows during the sampling period $(P=0.02)$. Plasma insulin tended to be greater in elite cows than in NA cows during the sampling period $(P=0.06)$, and a genetic group $(\mathrm{GG}) \times$ time interaction was detected $(P=0.03)$. All values were back-transformed LSM with $95 \%$ CI. $\dagger P \leq 0.01$. 

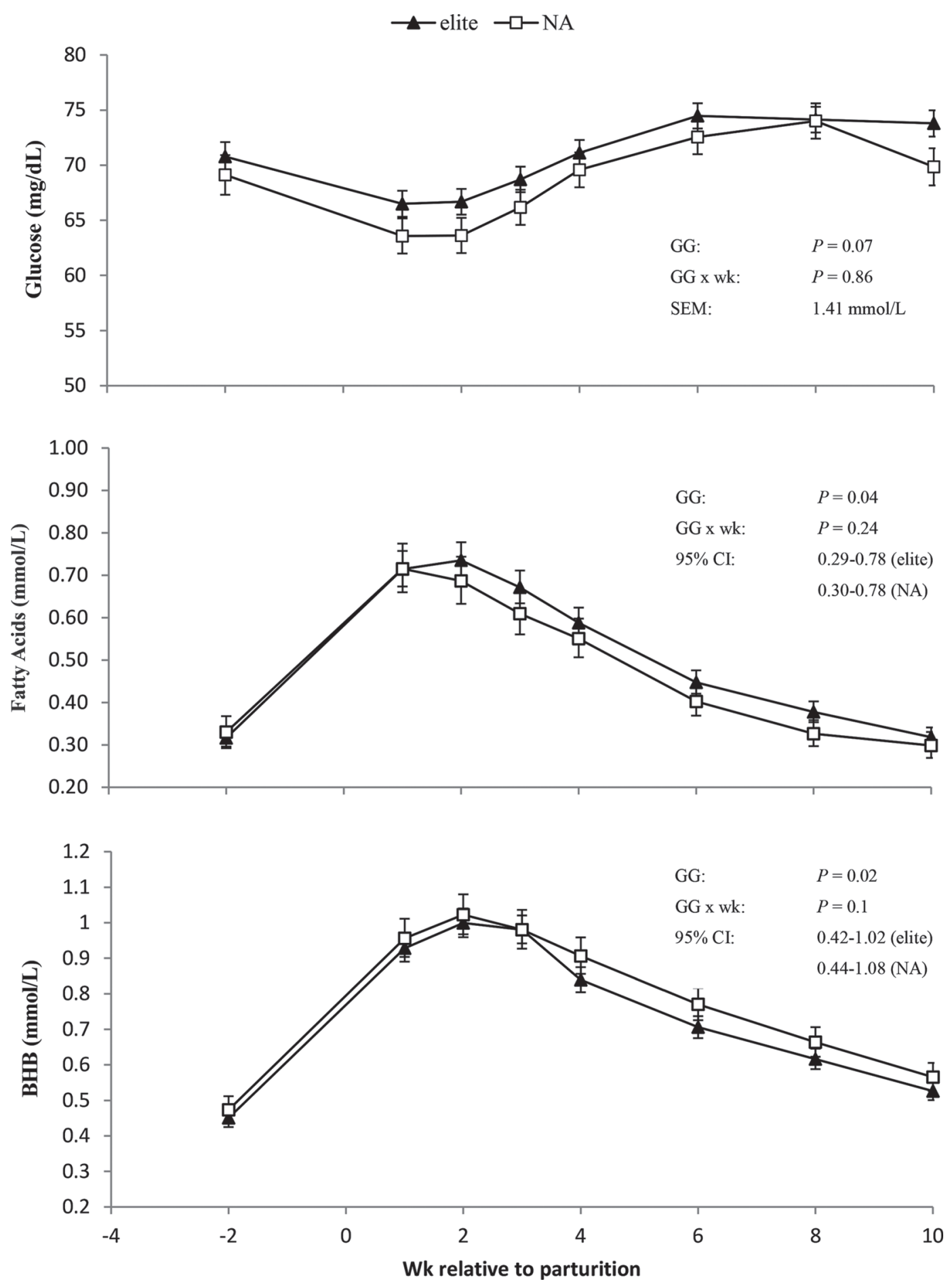

Figure 4. Mean circulating plasma glucose, fatty acids, and BHB concentrations in high Economic Breeding Index (elite) and national average Economic Breeding Index (NA) cows from wk -2 to 10 relative to parturition. Mean plasma glucose, fatty acids, and BHB were similar in both genetic groups (GG). Values for fatty acids and BHB are back-transformed LSM with 95\% CI.

tive success (Buckley et al., 2003). Holmes (1988) reported that changes in body condition during lactation were influenced by both the BCS at calving and the genetic index of the cow. Similarly, Buckley (1998) reported that mid- to late-lactation BCS is influenced by genetic merit for milk production. Horan et al. (2005) 
observed that a New Zealand strain of HF maintained higher BCS than a North American HF strain, which was attributed to the fact that the New Zealand strain were selected for more modest milk production and superior reproductive ability and survival than their North American counterpart. More recently, Cummins et al. (2012b) and Moore et al. (2014) both reported that greater genetic merit for fertility traits supports a greater threshold BCS. Past genetic selection for increased milk production resulted in greater postpartum adipose tissue mobilization to sustain high milk production (Roche et al., 2006; McCarthy et al., 2007b; Lucy et al., 2009), largely due to an inability to achieve sufficient energy intake to meet energetic requirements for milk production. Moore et al. (2014) reported that cows with good genetic merit for fertility traits had greater DMI in early lactation compared with cows that had poor genetic merit for fertility traits, supporting maintenance of greater BCS and milk production. The significantly higher DMI relative to BW, in addition to a slight reduction in the utilization of energy for milk production in elite cows reported by O'Sullivan et al. (2019a), facilitated more favorable energy balance in elite cows compared with NA, which contributed to greater BCS. In addition, a slightly reduced persistency in late lactation for elite cows was reported by O'Sullivan et al. (2019b), likely facilitating the apparent increase in the BCS gain in elite cows during late lactation. In contrast, NA cows experience a decline in BCS after parturition, followed by stable BCS throughout mid to late lactation, which may facilitate the more

Table 4. The effect of genetic group (GG) of Holstein-Friesian dairy cow on postpartum luteal activity based on the analysis of milk progesterone concentrations ${ }^{1}$

\begin{tabular}{|c|c|c|c|c|}
\hline \multirow[b]{2}{*}{ Item } & \multicolumn{2}{|c|}{ GG } & \multirow[b]{2}{*}{ SEM } & \multirow[b]{2}{*}{$P$-value } \\
\hline & Elite & NA & & \\
\hline C-LA (d) & 24.9 & 26.8 & 1.21 & 0.26 \\
\hline LP1 (d) & 10.6 & 10.7 & 0.35 & 0.85 \\
\hline ILI1 (d) & 4.6 & 4.3 & 0.22 & 0.33 \\
\hline IOI1 (d) & 19.2 & 19.0 & 0.38 & 0.79 \\
\hline LP2 (d) & 12.0 & 12.2 & 0.30 & 0.63 \\
\hline ILI2 (d) & 4.8 & 4.4 & 0.23 & 0.30 \\
\hline IOI2 (d) & 21.0 & 20.6 & 0.37 & 0.56 \\
\hline LP60d & 1.8 & 1.8 & 0.06 & 0.56 \\
\hline LP1 P4 (ng/mL) & 19.4 & 18.8 & 0.77 & 0.63 \\
\hline LP2 P4 (ng/mL) & 21.8 & 22.6 & 0.81 & 0.49 \\
\hline
\end{tabular}

${ }^{1}$ Elite $=$ high Economic Breeding Index; $\mathrm{NA}=$ national average Economic Breeding Index. C-LA = calving to commencement of luteal activity (luteal activity; milk progesterone $\geq 3 \mathrm{ng} / \mathrm{mL}$ ); LP1 = luteal phase 1 ; LP2 = luteal phase 2 ; IOI1 = inter-ovulatory interval 1 ; IOI2 $=$ inter-ovulatory interval 2 ; ILI1 $=$ inter-luteal interval 1 ; ILI2 = inter-luteal interval 2; LP60d $=$ number of luteal phases in the first 60 d postcalving; LP1 P4 = luteal phase 1 progesterone peak concentration; LP2 P4 = luteal phase 2 progesterone peak concentration. persistent lactation profile identified by O'Sullivan et al. (2019b). The observed differences in reproductive performance in the present study support the suggestion by O'Sullivan et al. (2019a) that differences in prioritization of energy utilization between GG contributed to the greater BCS, and consequently superior reproductive performance in elite cows.

\section{Energy Metabolites and Metabolic Hormones}

Greater circulating glucose, IGF-1, and insulin concentrations, and significantly lower BHB concentrations during the early lactation period indicate that elite cows were in a more favorable metabolic status compared with NA cows. A positive association between circulating glucose during the early postpartum period and likelihood of conception at first service has been reported (Green et al., 2012; Garverick et al., 2013; Moore et al., 2014). Circulating glucose concentrations during the immediate postpartum period may be a key indicator of a cow's adaptive ability to meet the demands of rising milk production while minimizing BCS loss (Moore et al., 2014). The findings of Moore et al. (2014) indicate that genetic selection for fertility traits results in more favorable glucose status in early lactation, which may represent a key inherent difference between cows with good or poor genetic merit for fertility traits. Similar trends have been observed in the present study, although the magnitude of difference observed was smaller than those observed by Moore et al. (2014). Greater IGF-1 concentrations in elite cows is consistent with a large body of evidence linking greater IGF-1 concentrations with improved reproductive outcomes (Taylor et al., 2004; Patton et al., 2007; Cummins et al., 2012b). The observed differences in circulating IGF-1 concentrations in the present study perhaps indicate a genetic effect in the regulation of the somatotropic axis, similar to that observed by (Cummins et al., 2012a,b). Insulin plays a central role in the metabolism of body tissues, acting as an indicator of energy status. In the present study the difference between GG in concentrations of glucose, insulin, and IGF-1 are consistent with the differences previously reported for cows with good versus poor genetic merit for fertility traits (Moore et al., 2014), and consistent with their interlinking roles in the regulation of the reproductive axis (Lucy et al., 2014). The tendency for greater insulin concentration in elite cows, therefore, may also have had a positive effect on the regulation of the somatotropic axis. The concentrations of plasma fatty acids were greater in elite cows, which was consistent with the BCS changes observed in these animals, particularly the numerically greater BCS loss during the period from calving to AI. 
A similar finding was reported by Coleman et al. (2009) comparing New Zealand versus North American strains of Holstein-Friesian cows. The elite cows had more BCS to lose, therefore exhibiting greater circulating concentrations of fatty acids. Body condition score losses from calving to AI were within the normal ranges, and did not exceed previously outlined levels of BCS loss known to hinder subsequent fertility performance (Buckley et al., 2005; Butler, 2005). Achieving high levels of milk production and simultaneously maintaining target BCS requires exquisite coordination of energy metabolism across multiple tissues (Moran et al., 2016). Therefore, the present study confirms that selection for high EBI not only contributes to higher BCS and greater reproductive efficiency, but also conveys a genetic predisposition for favorable metabolic and hormonal status.

\section{Ovarian Activity}

Progesterone profiles are useful for identifying the interval from calving to C-LA and examining estrous cycle characteristics. Ovulation within the first month postpartum is favorable for reproductive success (Galvão et al., 2010). Phenotypically, an early return to cyclic activity in postpartum cows has been associated with a shortened interval from calving to conception, increased conception rate, and fewer services per conception (Darwash et al., 1997). The interval to first ovulation is largely dependent on the endocrinology of the cow, which in turn is largely determined by energy balance postpartum (Lucy, 2019). None of the P4 profile variables were affected by genetics in the present study. Similar findings have also been previously reported (Pollott and Coffey, 2008; Walsh et al., 2008; Bedere et al., 2016). The observed interval from calving to C-LA was broadly consistent with the values reported for HF cows selected for EBI in the study of Leane (2018), but considerably shorter than the reported intervals from calving to C-LA in the study of Horan et al. (2006). This may be a reflection of the genetic distance between the cows in the respective studies as result of selection based on EBI. Although the present study indicates little differences in C-LA and estrous cycle characteristics between GG, previous studies have shown that abnormal ovarian activity is common, with only $60 \%$ of Holstein cows reported to have normal cyclicity, and the major abnormal cyclicity pattern detected is delayed C-LA (Petersson et al., 2006; Cutullic et al., 2011). Delayed C-LA has been reported in cows with the greatest EBV for milk yield (Windig et al., 2008;

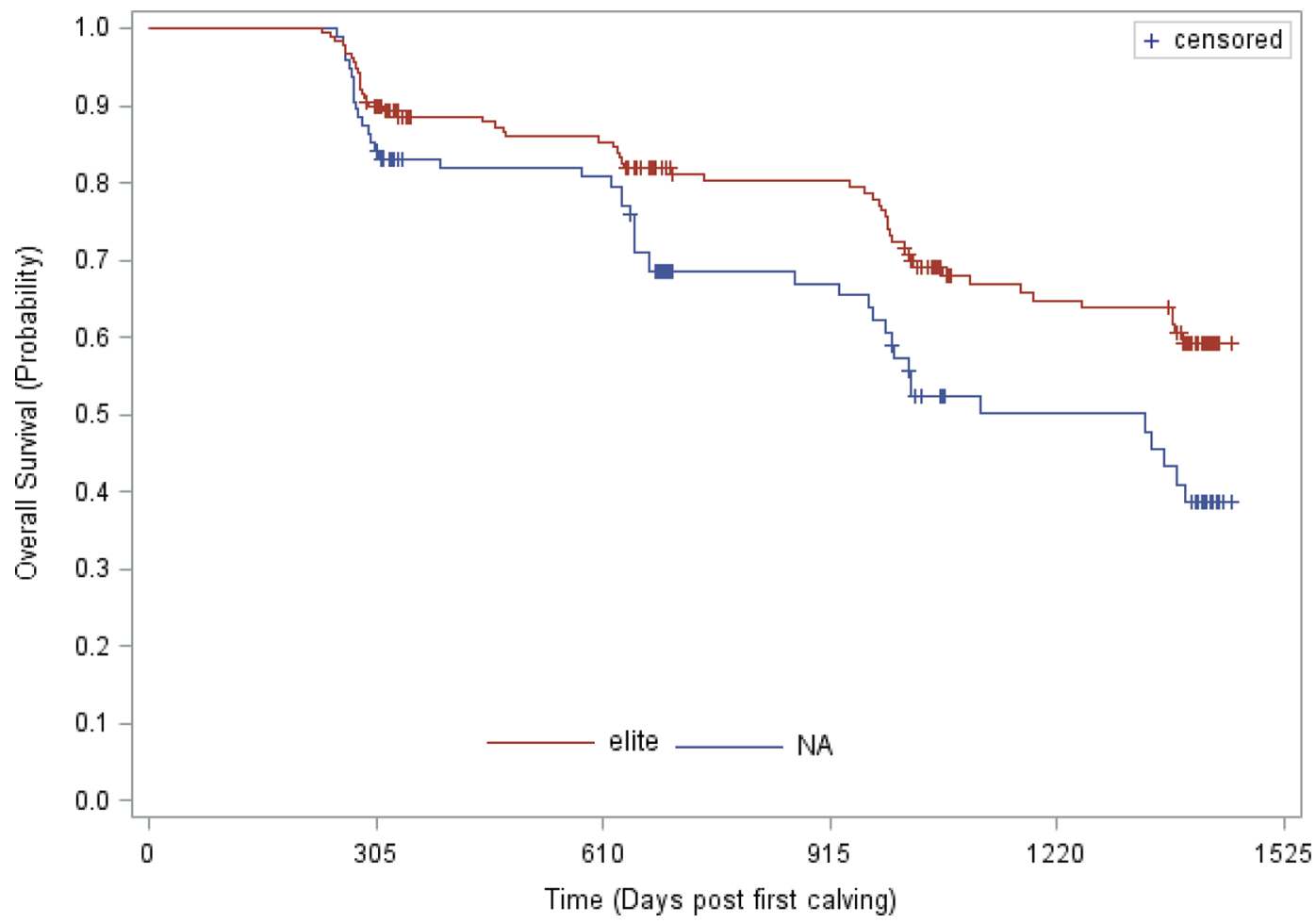

Figure 5. Survival curves for high Economic Breeding Index (elite) and national average Economic Breeding Index (NA) cows across days post-first calving during the 4 -yr study period. The y-axis represents the overall survival. The $x$-axis represents the number of days post-first calving. Log-rank test indicates different survival experiences observed between elite and NA $(P<0.01)$. 
Bedere et al., 2016). Interestingly, Bedere et al. (2016) suggested that exporting milk with higher fat and protein contents was associated with earlier C-LA. The high levels of milk constituents reported by O'Sullivan et al. (2019a) in both GG and the observed intervals from calving to C-LA in the present study indicate that the EBI milk and fertility sub-indices are working in tandem to generate cows with high milk solids production and more favorable fertility phenotypes.

\section{Survival}

With increased longevity, the mean production of the herd increases as a greater proportion of culling decisions are based on production, and the proportion of mature cows in the herd is increased (Sewalem et al., 2008). A dairy heifer will produce approximately $75 \%$ of a mature cow's milk yield (Hutchinson et al., 2013). Therefore, reductions in survivability often result in the genetic potential for milk production never being fully realized at farm level (Esslemont et al., 2001). Using data from commercial dairy farms in Ireland, Evans et al. (2006) reported that only $50 \%$ of the potential increase in farm profitability through increased milk production was realized because of poor reproductive performance, highlighting the financial importance of excellent reproductive efficiency. Lopez-Villalobos et al. (2000) reported a dual effect of increased survival on profitability through lower replacement rates and greater herd milk yields arising from a higher proportion of mature animals in a simulation study of seasonal calving herds in New Zealand. Similarly, previous economic analyses attributed increased profitability to greater lifetime milk production, achieved by way of increased longevity, and lower replacement rates in crossbred cows relative to their purebred contemporaries (Prendiville et al., 2011; Coffey et al., 2016). National statistics indicate the current average number of calvings per dairy cow in Ireland is 3.4 (ICBF, 2018). Therefore, considerable genetic improvement is required to increase dairy cow longevity. The greater survival of elite cows to the start of fifth lactation in the present study indicates that greater longevity is achieved though selection for high EBI. Thus, higher profitability with elite cows may be expected as a direct outcome of lower replacement rate and costs, as well as a greater proportion of the lactating herd reaching mature lactation potential (Shalloo et al., 2014).

\section{CONCLUSIONS}

Improving the reproductive efficiency of dairy cows is an overarching goal within the dairy industry today, es- pecially in seasonal-calving pasture-based systems. The present study clearly demonstrates that intensive selection for high EBI can reverse negative fertility trends incurred through past decades of selection for milk production alone and deliver reproductive performance and longevity consistent with industry targets. The mechanisms driving the differences in fertility include modest differences in metabolic and hormonal profiles and markedly greater BCS in elite cows compared with NA cows. The Next Generation Herd plays an important role as a futuristic national herd and industry-wide point of reference for reproductive performance achievable through selection for high EBI. Ultimately the present study highlights the potential influence of genetics to deliver genetic and phenotypic gain by placing appropriate emphasis on traits of economic importance within a selection objective.

\section{ACKNOWLEDGMENTS}

The authors thank the farm staff of the Dairygold Research Farm (Teagasc Animal and Grassland Research and Innovation Centre, Moorepark, Fermoy, Co. Cork, Ireland) for their care of the experimental animals. The authors acknowledge A. F. Parlow of the National Hormone and Peptide Program (NHPP, Torrance, CA) for provision of the IGF-I primary antibody (anti-human IGF-I; NHPP167 NIDDK AFP 4892898). We thank John Furlong (School of Veterinary Medicine, University College Dublin, Ireland) for technical assistance with IGF-I and insulin assays. The authors have not stated any conflicts of interest.

\section{REFERENCES}

Bedere, N., L. Delaby, V. Ducrocq, S. Leurent-Colette, and C. Disenhaus. 2016. Toward improved postpartum cyclicity of primiparous dairy cows: Effects of genetic merit for production traits under contrasting feeding systems. J. Dairy Sci. 99:1266-1276. https:// doi.org/10.3168/jds.2015-9843.

Beltman, M. E., N. Forde, P. Furney, F. Carter, J. F. Roche, P. Lonergan, and M. A. Crowe. 2010. Characterisation of endometrial gene expression and metabolic parameters in beef heifers yielding viable or non-viable embryos on Day 7 after insemination. Reprod. Fertil. Dev. 22:987-999.

Berry, D. P. 2015. Breeding the dairy cow of the future: What do we need? Anim. Prod. Sci. 55:823-837. https://doi.org/10.1071/ AN14835.

Berry, D. P., F. Buckley, P. Dillon, R. D. Evans, M. Rath, and R. F. Veerkamp. 2003. Genetic parameters for body condition score, body weight, milk yield, and fertility estimated using random regression models. J. Dairy Sci. 86:3704-3717. https://doi.org/10 .3168/jds.S0022-0302(03)73976-9.

Berry, D. P., J. R. Roche, and M. P. Coffey. 2008. Body condition score and fertility - More than just a feeling. Pages 107-118 in Fertility in Dairy Cows: Bridging the Gaps. M. D. Royal, N. C. Friggens, and R. F. Smith, ed. British Society of Animal Science/ Cambridge University Press, Cambridge, UK. 
Bouquet, A., and J. Juga. 2013. Integrating genomic selection into dairy cattle breeding programmes: A review. Animal 7:705-713. https://doi.org/10.1017/S1751731112002248.

Buckley, F. 1998. Effect of genotype of cow and system of feeding on milk production, feed intake and nutrient utilisation of spring-calving Holstein-Friesian dairy cows in Ireland. PhD Thesis. University College Dublin, Ireland.

Buckley, F., P. Dillon, M. Rath, and R. F. Veerkamp. 2000. The relationship between genetic merit for yield and live weight, condition score, and energy balance of spring calving Holstein Friesian dairy cows on grass based systems of milk production. J. Dairy Sci. 83:1878-1886. https://doi.org/10.3168/jds.S0022-0302(00)75060 $-0$.

Buckley, F., C. Holmes, and M. G. Keane. 2005. Genetic characteristics required in dairy and beef cattle for temperate grazing systems. Utilisation of grazed grass in temperate animal systems. J. H. Murphy, ed. Pages 61-79 in Proceeding of a Satellite Workshop of the XXth International Grassland Congress. Wageningen Academic Publishers, Wageningen, the Netherlands.

Buckley, F., K. O'Sullivan, J. F. Mee, R. D. Evans, and P. Dillon. 2003. Relationships among milk yield, body condition, cow weight, and reproduction in spring-calved Holstein-Friesians. J. Dairy Sci. 86:2308-2319. https://doi.org/10.3168/jds.S0022-0302(03)73823 -5 .

Butler, W. 2005. Nutrition, negative energy balance and fertility in the postpartum dairy cow. Cattle Pract. 13:13-18.

Coffey, E., B. Horan, R. Evans, and D. Berry. 2016. Milk production and fertility performance of Holstein, Friesian, and Jersey purebred cows and their respective crosses in seasonal-calving commercial farms. J. Dairy Sci. 99:5681-5689. https://doi.org/10.3168/ jds.2015-10530.

Cole, J. B., and P. M. VanRaden. 2018. Symposium review: Possibilities in an age of genomics: The future of selection indices. J. Dairy Sci. 101:3686-3701. https://doi.org/10.3168/jds.2017-13335.

Coleman, J., K. M. Pierce, D. P. Berry, A. Brennan, and B. Horan. 2009. The influence of genetic selection and feed system on the reproductive performance of spring-calving dairy cows within future pasture-based production systems. J. Dairy Sci. 92:5258-5269. https://doi.org/10.3168/jds.2009-2108.

Council of the European Union. 1986. Council Directive 86/609/EEC of 24 November 1986 on the approximation of laws, regulations and administrative provisions of the Member States regarding the protection of animals used for experimental and other scientific purposes. http://data.europa.eu/eli/dir/1986/609/oj.

Cummins, S. B., P. Lonergan, A. Evans, and S. T. Butler. 2012a. Genetic merit for fertility traits in Holstein cows: II. Ovarian follicular and corpus luteum dynamics, reproductive hormones, and estrus behavior. J. Dairy Sci. 95:3698-3710. https://doi.org/10 $.3168 /$ jds.2011-4976.

Cummins, S. B., P. Lonergan, A. C. Evans, D. P. Berry, R. D. Evans, and S. T. Butler. 2012b. Genetic merit for fertility traits in Holstein cows: I. Production characteristics and reproductive efficiency in a pasture-based system. J. Dairy Sci. 95:1310-1322. https://doi.org/10.3168/jds.2011-4742.

Cutullic, E., L. Delaby, Y. Gallard, and C. Disenhaus. 2011. Dairy cows' reproductive response to feeding level differs according to the reproductive stage and the breed. Animal 5:731-740. https:// doi.org/10.1017/S1751731110002235.

DairyNZ. 2019. Economic Values 2019. Accessed Jan. 10, 2019. https: //www.dairynz.co.nz/animal/animal-evaluation/interpreting-the -info/economic-values/.

Darwash, A., G. Lamming, and J. Wooliams. 1997. The phenotypic association between the interval to post-partum ovulation and traditional measures of fertility in dairy cattle. J. Anim. Sci. 65:9-16. https://doi.org/10.1017/S1357729800016234.

Department of Health and Children. Ireland. 2005. European Communities (Amendment of Cruelty to Animals Act 1876) Regulations 2005. S.I. No. 613/2005. http://www.irishstatutebook.ie/eli/2005/ si $/ 613 /$ made/en/print

Domecq, J., A. Skidmore, J. Lloyd, and J. Kaneene. 1997. Relationship between body. condition scores and conception at first arti- ficial insemination in a large dairy herd of high yielding Holstein cows. J. Dairy Sci. 80:113-120. https://doi.org/10.3168/jds.S0022 -0302(97)75918-6.

Edmonson, A. J., I. J. Lean, L. D. Weaver, T. Farver, and G. Webster. 1989. A body condition scoring chart for Holstein cows. J. Dairy Sci. 72:68-78. https://doi.org/10.3168/jds.S0022-0302(89)79081-0.

Esslemont, R., M. Kossaibati, and J. Allcock. 2001. Economics of fertility in dairy cows. Recording and evaluation of fertility traits in UK dairy herd. Pages $5-15$ in Proceedings of a workshop, 19th and 20th November, 2001, Edinburgh, Scotland.

Evans, R. D., P. Dillon, F. Buckley, D. P. Berry, M. Wallace, V. Ducrocq, and D. J. Garrick. 2006. Trends in milk production, calving rate and survival of cows in 14 Irish dairy herds as a result of the introgression of Holstein-Friesian genes. Anim. Sci. 82:423-433. https://doi.org/10.1079/ASC200660.

Fleming, A., C. F. Baes, A. A. A. Martin, T. C. S. Chud, F. Malchiodi, L. F. Brito, and F. Miglior. 2019. Symposium review: The choice and collection of new relevant phenotypes for fertility selection. J. Dairy Sci. 102:3722-3734. https://doi.org/10.3168/jds.2018-15470.

Galvão, K. N., M. Frajblat, W. R. Butler, S. B. Brittin, C. L. Guard, and R. O. Gilbert. 2010. Effect of early postpartum ovulation on fertility in dairy cows. Reprod. Domest. Anim. 45:e207-e211.

Garverick, H., M. Harris, R. Vogel-Bluel, J. Sampson, J. Bader, W. Lamberson, J. Spain, M. Lucy, and R. Youngquist. 2013. Concentrations of nonesterified fatty acids and glucose in blood of periparturient dairy cows are indicative of pregnancy success at first insemination. J. Dairy Sci. 96:181-188. https://doi.org/10.3168/ jds.2012-5619.

Green, J. C., J. P. Meyer, A. M. Williams, E. M. Newsom, D. H Keisler, and M. C. Lucy. 2012. Pregnancy development from day 28 to 42 of gestation in postpartum Holstein cows that were either milked (lactating) or not milked (not lactating) after calving. Reproduction 143:699-711. https://doi.org/10.1530/REP-11-0461.

Holmes, C. W. 1988. Genetic merit and efficiency of milk production by the dairy cow. In Nutrition and Lactation in the Dairy Cow. P. C. Garnsworthy, ed. Butterworths, Oxford, United Kingdom.

Horan, B., P. Faverdin, L. Delaby, M. Rath, and P. Dillon. 2006. The effect of strain of Holstein-Friesian dairy cow and pasture-based system on grass intake and milk production. Anim. Sci. 82:435444. https://doi.org/10.1079/ASC200661.

Horan, B., J. Mee, P. O'Connor, M. Rath, and P. Dillon. 2005. The effect of strain of Holstein-Friesian cow and feeding system on postpartum ovarian function, animal production and conception rate to first service. Theriogenology 63:950-971. https://doi.org/ 10.1016/j.theriogenology.2004.05.014.

Horan, B., J. F. Mee, M. Rath, P. O. Connor, and P. Dillon. 2004. The effect of strain of Holstein-Friesian cow and feeding system on reproductive performance in seasonal-calving milk production systems. Anim. Sci. 79:453-467. https://doi.org/10.1017/ S1357729800090329.

Hutchinson, I. A., L. Shalloo, and S. T. Butler. 2013. Expanding the dairy herd in pasture-based systems: The role for sexed semen use on virgin heifers. J. Dairy Sci. 96:1312-1322. https://doi.org/10 .3168/jds.2012-6126.

ICBF. 2017. Update to Economic Values in the EBI. Accessed Jan. 20, 2018. https:/ /www.icbf.com/wp/?p=9695.

ICBF. 2018. Dairy Calving Statistics 2008-2018. Accessed Jan. 20, 2019. https://www.icbf.com/wp/wp-content/uploads/2018/09/ Dairy-Calving-Stats-2018- 1.pdf.

Kennedy, J., P. Dillon, P. Faverdin, L. Delaby, F. Buckley, and M. Rath. 2002. The influence of cow genetic merit for milk production on response to level of concentrate supplementation in a grassbased system. Anim. Sci. 75:433-445. https://doi.org/10.1017/ S1357729800053200.

Leane, S. 2018. Nutritional effects on reproduction in pasture-based systems of dairy production. PhD Thesis. University College Dublin, Ireland.

Lopez-Villalobos, N., D. J. Garrick, C. W. Holmes, H. T. Blair, and R. J. Spelman. 2000. Profitabilities of some mating systems for dairy herds in New Zealand. J. Dairy Sci. 83:144-153. https://doi.org/ 10.3168/jds.S0022-0302(00)74865-X. 
Lucy, M. C. 2019. Symposium review: Selection for fertility in the modern dairy cow- Current status and future direction for genetic selection. J. Dairy Sci. 102:3706-3721. https://doi.org/10.3168/jds .2018-15544.

Lucy, M. C., S. Butler, and H. Garverick. 2014. Endocrine and metabolic mechanisms linking postpartum glucose with early embryonic and foetal development in dairy cows. Animal 8(s1):82-90. https:/ /doi.org/10.1017/S1751731114000482.

Lucy, M. C., G. Verkerk, B. Whyte, K. Macdonald, L. Burton, R. Cursons, J. Roche, and C. Holmes. 2009. Somatotropic axis components and nutrient partitioning in genetically diverse dairy cows managed under different feed allowances in a pasture system. J. Dairy Sci. 92:526-539. https://doi.org/10.3168/jds.2008-1421.

Macmillan, K. L. 2012. Developing a breeding program for compact calving. Pages 72-80 in Dairy Cow Fertility - Reproductive performance for efficient pasture-based systems. International Conference. Rochestown Park Hotel, Cork, Ireland.

McCarthy, S., D. P. Berry, P. Dillon, M. Rath, and B. Horan. 2007b. Influence of Holstein-Friesian strain and feed system on body weight and body condition score lactation profiles. J. Dairy Sci. 90:1859-1869. https://doi.org/10.3168/jds.2006-501.

McCarthy, S., B. Horan, P. Dillon, P. O'Connor, M. Rath, and L. Shalloo. 2007a. Economic comparison of divergent strains of Holstein-Friesian cows in various pasture-based production systems. J. Dairy Sci. 90:1493-1505. https://doi.org/10.3168/jds.S0022 $-0302(07) 71635-1$.

McDougall, S. 2006. Reproduction performance and management of dairy cattle. J. Reprod. Dev. 52:185-194. https://doi.org/10.1262/ jrd.17091.

Miglior, F., J. Chesnais, and B. Van Doormaal. 2012. Genetic improvement: a major component of increased dairy farm profitability. Invited Presentation at 38th ICAR Biennial Session held in Cork, Ireland.

Miglior, F., A. Fleming, F. Malchiodi, L. F. Brito, P. Martin, and C. F. Baes. 2017. A 100- Year Review: Identification and genetic selection of economically important traits in dairy cattle. J. Dairy Sci. 100:10251-10271. https://doi.org/10.3168/jds.2017-12968.

Miglior, F., B. L. Muir, and B. J. Van Doormaal. 2005. Selection indices in Holstein cattle of various countries. J. Dairy Sci. 88:12551263. https://doi.org/10.3168/jds.S0022-0302(05)72792-2.

Moore, S., T. Fair, P. Lonergan, and S. Butler. 2014. Genetic merit for fertility traits in Holstein cows: IV. Transition period, uterine health, and resumption of cyclicity. J. Dairy Sci. 97:2740-2752. https://doi.org/10.3168/jds.2013-7278.

Moran, B., S. B. Cummins, C. J. Creevey, and S. T. Butler. 2016. Transcriptomics of liver and muscle in Holstein cows genetically divergent for fertility highlight differences in nutrient partitioning and inflammation processes. BMC Genomics 17:603. https://doi .org/10.1186/s12864-016-2938-1.

O'Donovan, M., E. Lewis, and P. O'Kiely. 2011. Requirements of future grass-based ruminant production systems in Ireland. Ir. J. Agric. Food Res. 50:1-21.

O'Farrell, K. 1994. Measurement of fertility in seasonally-calving dairy herds. R \& H Hall Technical Bulletin Issue (2).

O'Sullivan, M., P. Dillon, K. O'Sullivan, K. M. Pierce, N. Galvin, and F. Buckley. 2019a. Intake, efficiency, and feeding behavior characteristics of Holstein-Friesian cows of divergent Economic Breeding Index evaluated under contrasting pasture-based feeding treatments. J. Dairy Sci. 102:8234-8246. https://doi.org/10.3168/ jds.2019-16371.

O'Sullivan, M., B. Horan, K. M. Pierce, S. McParland, K. O'Sullivan, and F. Buckley. 2019b. Milk production of Holstein-Friesian cows of divergent Economic Breeding Index evaluated under seasonal pasture-based management. J. Dairy Sci. 102:2560-2577. https:// doi.org/10.3168/jds.2018-15559.

Patton, J., D. Kenny, S. McNamara, J. Mee, F. O'Mara, M. Diskin, and J. Murphy. 2007. Relationships among milk production, energy balance, plasma analytes, and reproduction in Holstein-Friesian cows. J. Dairy Sci. 90:649-658. https://doi.org/10.3168/jds.S0022 $-0302(07) 71547-3$.
Petersson, K.-J., H. Gustafsson, E. Strandberg, and B. Berglund. 2006. Atypical progesterone profiles and fertility in Swedish dairy cows. J. Dairy Sci. 89:2529-2538. https://doi.org/10.3168/jds .S0022-0302(06)72328-1.

Pollott, G., and M. Coffey. 2008. The effect of genetic merit and production system on dairy cow fertility, measured using progesterone profiles and on-farm recording. J. Dairy Sci. 91:3649-3660. https:/ /doi.org/10.3168/jds.2007-0913.

Prendiville, R., L. Shalloo, K. M. Pierce, and F. Buckley. 2011. Comparative performance and economic appraisal of Holstein-Friesian, Jersey and Jersey x Holstein-Friesian cows under seasonal pasturebased management. Ir. J. Agric. Food Res. 50:123-140.

Pritchard, T., M. Coffey, R. Mrode, and E. Wall. 2013. Genetic parameters for production, health, fertility and longevity traits in dairy cows. Animal 7:34-46. https://doi.org/10.1017/ S1751731112001401.

Pryce, J., M. Royal, P. Garnsworthy, and I. L. Mao. 2004. Fertility in the high-producing dairy cow. Livest. Prod. Sci. 86:125-135. https: //doi.org/10.1016/S0301-6226(03)00145-3.

Pryce, J., R. Woolaston. D. Berry, E. Wall, M. Winters, R. Butler, and M. Shaffer. 2014. World trends in dairy cow fertility. In Proc. 10th World Congress on Genetics Applied to Livestock Production, Vancouver, Canada. American Society of Animal Science, Champaign, IL.

Pryce, J. E., M. P. Coffey, and G. Simm. 2001. The relationship between body condition score and reproductive performance. J. Dairy Sci. 84:1508-1515. https://doi.org/10.3168/jds.S0022 $-0302(01) 70184-1$.

Pryce, J. E., and R. F. Veerkamp. 2001. The incorporation of fertility indices in genetic improvement programmes. British Society of Animal Science Occasional Publication on Fertility in the High Production Dairy cow. 26:237-249.

Roche, J. R., D. P. Berry, and E. S. Kolver. 2006. Holstein-Friesian strain and feed effects on milk production, body weight, and body condition score profiles in grazing dairy cows. J. Dairy Sci. 89:3532-3543. https://doi.org/10.3168/jds.S0022-0302(06)72393 $-1$.

Sewalem, A., F. Miglior, G. J. Kistemaker, P. Sullivan, and B. J. Van Doormaal. 2008. Relationship between reproduction traits and functional longevity in Canadian dairy cattle. J. Dairy Sci 91:1660-1668. https://doi.org/10.3168/jds.2007-0178.

Shalloo, L., A. Cromie, and N. McHugh. 2014. Effect of fertility on the economics of pasture-based dairy systems. Animal 8(Suppl.1):222-231. https://doi.org/10.1017/S1751731114000615.

Shalloo, L., S. O'Donnell, and B. Horan. 2007. Profitable dairying in an increased EU milk quota scenario. Exploiting the freedom to milk. Pages $20-42$ in Proceedings of the Teagasc National Dairy Conference.

Snijders, S. E. M., P. G. Dillon, K. J. O'Farrell, M. Diskin, A. R. G. Wylie, D. O'Callaghan, M. Rath, and M. P. Boland. 2001. Genetic merit for milk production and reproductive success in dairy cows. Anim. Reprod. Sci. 65:17-31. https://doi.org/10.1016/S0378 $-4320(00) 00217-7$.

Steinfeld, H., and J. Mäki-Hokkonen. 1995. A classification of livestock production systems. Wld. Anim. Rev. 83-94.

Taylor, V.. Z. Cheng, P. Pushpakumara, D. Beever, and D. Wathes. 2004. Relationships between the plasma concentrations of insulinlike growth factor-I in dairy cows and their fertility and milk yield. Vet. Rec. 155:583-588. https://doi.org/10.1136/vr.155.19.583.

Tiezzi, F., C. Maltecca, A. Cecchinato, M. Penasa, and G. Bittante. 2013. Thin and fat cows, and the nonlinear genetic relationship between body condition score and fertility. J. Dairy Sci. 96:67306741. https://doi.org/10.3168/jds.2013-6863.

VandeHaar, M. J., L. E. Armentano, K. Weigel, D. M. Spurlock, R. J. Tempelman, and R. Veerkamp. 2016. Harnessing the genetics of the modern dairy cow to continue improvements in feed efficiency. J. Dairy Sci. 99:4941-4954. https://doi.org/10.3168/jds .2015-10352.

Veerkamp, R. F., B. Beerda, and T. van der Lende. 2003. Effects of genetic selection for milk yield on energy balance, levels of hormones, 
and metabolites in lactating cattle, and possible links to reduced fertility. Livest. Prod. Sci. 83:257-275. https://doi.org/10.1016/ S0301-6226(03)00108-8.

Veerkamp, R. F., P. Dillon, E. Kelly, A. R. Cromie, and A. F. Groen. 2002. Dairy cattle breeding objectives combining yield, survival and calving interval for pasture-based systems in Ireland under different milk quota scenarios. Livest. Prod. Sci. 76:137-151. https: //doi.org/10.1016/S0301-6226(02)00006-4

Veerkamp, R. F., E. P. C. Koenen, and G. De Jong. 2001. Genetic correlations among body condition score, yield, and fertility in firstparity cows estimated by random regression models. J. Dairy Sci. 84:2327-2335. https://doi.org/10.3168/jds.S0022-0302(01)74681 $-4$

Walsh, S., F. Buckley, K. Pierce, N. Byrne, J. Patton, and P. Dillon. 2008. Effects of breed and feeding system on milk production, body weight, body condition score, reproductive performance, and postpartum ovarian function. J. Dairy Sci. 91:4401-4413. https:// doi.org/10.3168/jds.2007-0818.

Washburn, S. P., W. Silvia, C. Brown, B. McDaniel, and A. McAllister. 2002. Trends in reproductive performance in southeastern Holstein and Jersey DHI herds. J. Dairy Sci. 85:244-251. https:// doi.org/10.3168/jds.S0022-0302(02)74073-3.
Weigel, K. A. 2006. Prospects for improving reproductive performance through genetic selection. Anim. Reprod. Sci. 96:323-330. https:/ /doi.org/10.1016/j.anireprosci.2006.08.010.

Windig, J., B. Beerda, and R. Veerkamp. 2008. Relationship between milk progesterone profiles and genetic merit for milk production, milking frequency, and feeding regimen in dairy cattle. J. Dairy Sci. 91:2874-2884. https://doi.org/10.3168/jds.2007-0111.

Zink, V., M. Štípková, and J. Lassen. 2011. Genetic parameters for female fertility, locomotion, body condition score, and linear type traits in Czech Holstein cattle. J. Dairy Sci. 94:5176-5182. https:/ /doi.org/10.3168/jds.2010-3644.

\section{ORCIDS}

M. O’Sullivan ( https://orcid.org/0000-0002-8758-4496

S. T. Butler (1) https://orcid.org/0000-0003-1542-8344

K. M. Pierce (ㄴ) https://orcid.org/0000-0002-2056-6189

M. Crowe (ํ) https://orcid.org/0000-0003-1999-815X

K. O’Sullivan (1) https://orcid.org/0000-0003-4393-5810 